\title{
Development of Unmanned Deep Foundation Construction Method in Shaft
}

\author{
Masao Shimizu* Kenji Sasaki* Takuro Shigeno* \\ Akio Hirata** Hironobu Nagase** Tomoo Mimura***
}

*Chubu Electric Power Co. Inc. Technical Section Transmission\& Substation Construction Office

2-3-24 Atutaku Yokota Nagoya-shi Japan email: CEQ01453@niftyserve.or.jp

**Kumagai Gumi Co. , Ltd Nagoya Branch Civil Engineering Department

1-1-5 Nishihioki Nakagawału Nagoya-shi Japan

***Kumagai Gumi Co., Ltd. Technology Development Division Production Technology Development Department

2-1 Tsukudo-cho Shinjuku-ku Tokyo Japan

\begin{abstract}
Deep foundations, because of their economical merits, are frequently used as foundation for steel transmission towers and bridges which are provided in mountain areas, as well as for landslide-restraining pile at scarps. However, the most of the works such as excavation are implemented in a narrow circular vertical shaft by human labor, with extremely severe work environment. Improvement of work environment, enhancement of safety, labor saving, shortening of construction period and cost reduction for deep foundation works by mechanization and automation are of primary concern. To overcome these difficulties, we have successfully developed a comprehensive unmanned construction system which is very innovative in conception and able to cover, from excavation to concrete placing, that is, "unmanned deep foundation construction method in shaft".

The paper outlines various technology elements, including the deep foundation excavator, the results of field tests, as well as its applicability to the foundation for steel transmission tower and the expected improvements.
\end{abstract}

\section{Introduction}

The deep foundation is a cylindric foundation of about $3 \mathrm{~m}$ in diameter and $20 \mathrm{~m}$ deep, having a large load resistance and able to be constructed in a relatively small space. Having the advantage of being constructed at low cost, it has being used in many cases for foundations of steel transmission towers, of road bridges, and as landslide preventing piles which are provided in mountain areas. Generally, deep foundations have been largely constructed by manual labor, because it is constructed in geographically disadvantageous spots with various restrictions in transportation and site space, in such mountain areas, introduction of large scale construction machine is difficult. Since the works are conducted in a circular space restricted in space with severe work environments, recruitment of quality manpower is harder and harder, on the background that the labor population of Japan decreases dramatically.

Therefore, improvement of work environment, enhancement of safety, labor saving, shortening of work periods for the construction of deep foundations and cost reduction through the mechanization and automatization are the topics of deep concern.

\section{Summary of the unmanned construction method in shaft}

Fig. 1 illustrates a series of process steps from excavation to concrete placing. This method aims to implement various works using no manpower in the shaft when constructing deep foundations, for the works such as excavation, bar arrangement and concrete placing. For this purpose, a comprehensive construction technology together with its elemental procedures was investigated and confirmed for its feasibility, setting up the following target items:

(1)In-shaft unmanned excavation by full face deep foundation excavator.

(2)Reinforcement cage-placing method, including assembling of cage outside the shaft and placing of 
cage in shaft.

(3) Development of concrete of self-filling type for deep foundation, including compaction-free concrete-placing technology

(4) Study on possibility of omitting temporary earth retaining

\section{Excavation system}

\section{(1) Excavation}

Digging of deep foundation by the in-shaft unmanned excavator

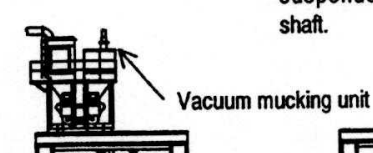

(2) Bar arrangement

The reinforcement cage is assembled on the platform, and with a suspension unit, is suspended in place in the shaft.

\subsection{Composition of the excavation system}

The excavation system consists of a main body of excavator, mucking system, suspension unit, remote controller and power unit. The configuration of the excavation system is shown in Fig. 2. The main specifications and performances are shown in Tables 1 and 2.

(3) Concrete placing

Concrete of self-settling type for deep foundation is placed without vibration.
(4) Completion

A leg frame is installed, and concrete is poured therein, and the works are completed with back filling.

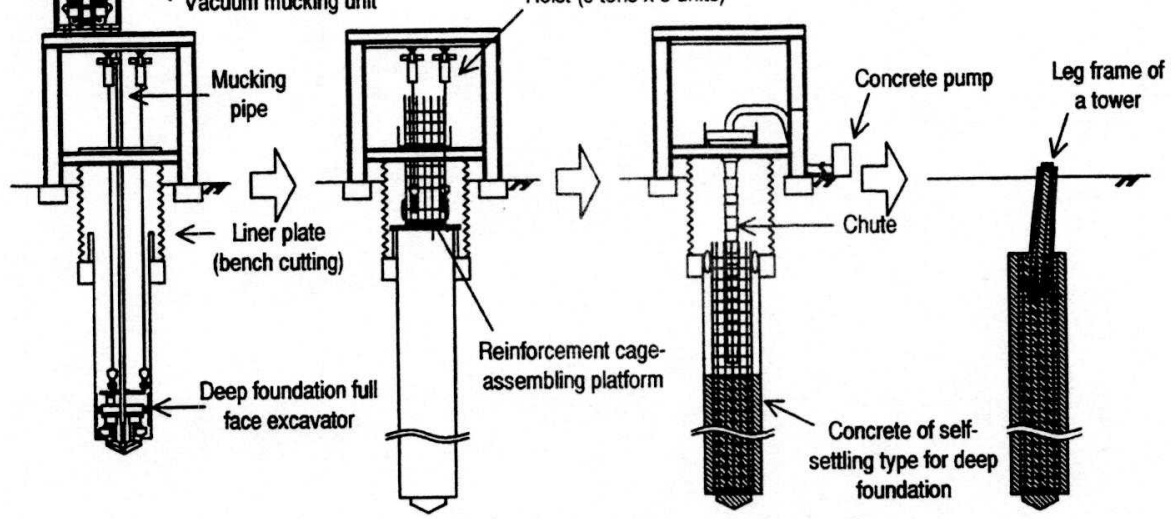

Fig. 1 Work steps for the in-shaft unmanned excavation

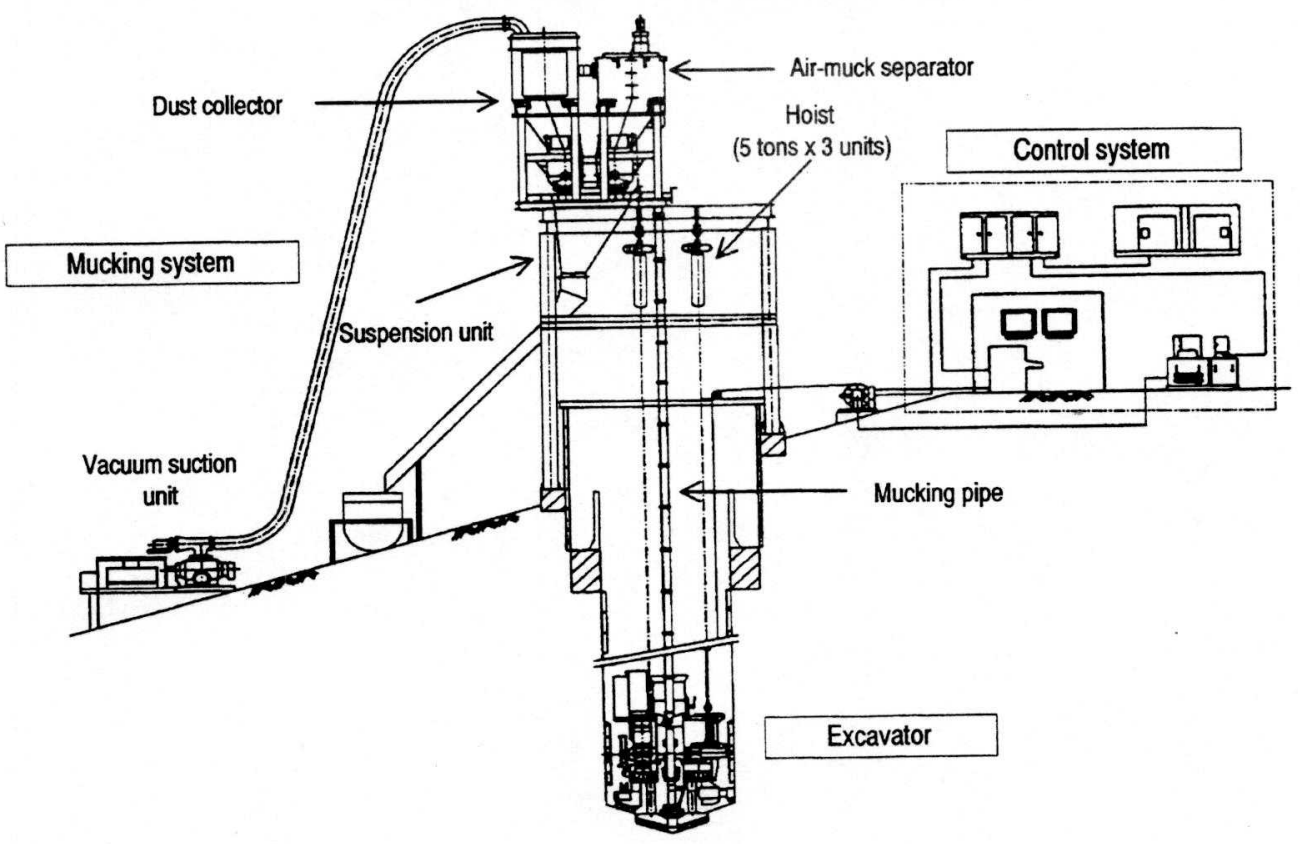

Fig. 2 Diagram of the entire deep foundation full-face excavator 
Table 1 Main specifications of the excavator

\begin{tabular}{|c|c|c|c|}
\hline \multicolumn{3}{|c|}{ Item } & Specifications \\
\hline \multirow{9}{*}{ 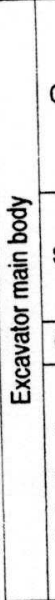 } & \multirow{3}{*}{ Cutter } & rpm of cutter & $\begin{array}{l}\text { Central cutter } 4.7 \mathrm{rpm} \\
\text { Circumference cutter } 3.3 \mathrm{~mm}\end{array}$ \\
\hline & & Cutter torque & $\begin{array}{l}\text { Central cutter } 55.9 \mathrm{kN} \mathrm{m} \\
\text { Circumference cutter } 79.4 \mathrm{kN} \mathrm{m}\end{array}$ \\
\hline & & Motor & $\begin{array}{l}18.5 \mathrm{~kW} \times 4 \mathrm{p} \\
220 \mathrm{~V} \times 60 \mathrm{~Hz} \text {, 3units }\end{array}$ \\
\hline & \multicolumn{2}{|l|}{ Shift jack } & $\begin{array}{l}78.5 \mathrm{kN} \times 550 \mathrm{~mm}, 3 \text { jacks } \\
\text { Total propelling force, } 235.5 \mathrm{kN} \\
\text { Telescopic speed (Max) } \\
5.6 \mathrm{~cm} / \mathrm{min}\end{array}$ \\
\hline & \multicolumn{2}{|l|}{ Gripper jack } & $240 \mathrm{kN} \times 300 \mathrm{~mm}, 3 \mathrm{jaks}$ \\
\hline & \multirow[b]{2}{*}{ Shifting } & Hydraulic pump & $0.28 \mathrm{~L} / \mathrm{min} \times 3 \times 15.7 \mathrm{MPa}$ \\
\hline & & Motor & $\begin{array}{l}0.4 \mathrm{~kW} \times 4 \mathrm{p} \\
220 \mathrm{~V} \times 60 \mathrm{~Hz} \text {, 1unit }\end{array}$ \\
\hline & \multirow[b]{2}{*}{ Gripper } & Hydraulic pump & $6.4 \mathrm{~L} / \mathrm{min} \times 3 \times 15.7 \mathrm{MPa}$ \\
\hline & & Motor & $\begin{array}{l}7.5 \mathrm{~kW} \times 4 \mathrm{p} \\
220 \mathrm{~V} \times 60 \mathrm{~Hz} \text {, tunit }\end{array}$ \\
\hline \multirow{8}{*}{ 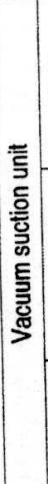 } & \multirow{3}{*}{$\begin{array}{l}\text { Vacuum } \\
\text { suction unit }\end{array}$} & Engine & $\begin{array}{l}\text { Air cooled diesel engine } \\
76 \mathrm{~kW} 2300 \mathrm{rpm}\end{array}$ \\
\hline & & Vacuum pump & 250A Root blower \\
\hline & & $\begin{array}{l}\text { Theoretical treatment } \\
\text { capacity }\end{array}$ & $98 \mathrm{kN} / \mathrm{h}$ \\
\hline & \multirow{3}{*}{$\begin{array}{l}\text { Air / muck } \\
\text { separating } \\
\text { collector }\end{array}$} & Motor & $\begin{array}{l}1.5 \mathrm{~kW} \times 4 \mathrm{p} \\
220 \mathrm{~V} \times 60 \mathrm{~Hz} \text { 1unit }\end{array}$ \\
\hline & & Dust removing & Air pulsation \\
\hline & & Required air volume & $360 \mathrm{NL} / \min \times 0.5 \mathrm{MPa}(\mathrm{G})$ \\
\hline & \multirow{2}{*}{$\begin{array}{l}\text { Mucking unit } \\
\text { of continuous } \\
\text { operation }\end{array}$} & Motor & $\begin{array}{l}0.75 \mathrm{~kW} \times 4 \mathrm{p} \\
220 \mathrm{~V} \times 60 \mathrm{~Hz} \text { 2units }\end{array}$ \\
\hline & & $\begin{array}{l}\text { Maximum mucking } \\
\text { capacity }\end{array}$ & $0.3 \mathrm{~m}^{3} / \mathrm{min}$ \\
\hline
\end{tabular}

Table 2 Performance of the excavator

\begin{tabular}{|c|c|}
\hline Item & Performance \\
\hline Excavation diameter & from $2.50 \mathrm{~m}$ to $3.35 \mathrm{~m}$ \\
\hline Excavation ground & $\begin{array}{l}\text { Ordinal soil to rock of middle hardness } \\
\text { (unconfined compressive strength : up to } 50 \mathrm{~N} \text {, } \\
\mathrm{mm}^{2} \text { ) }\end{array}$ \\
\hline Excavation depth & $35 \mathrm{~m}$ or less \\
\hline $\begin{array}{l}\text { Weight of each of the elements } \\
\text { constituting the system }\end{array}$ & 2.0 ton or less \\
\hline Total weight & About 12 ton (excavator only) \\
\hline Excavation speed & $\begin{array}{l}\text { Sand stone : } 60 \mathrm{~cm} / \mathrm{h} \\
\text { Soft rock : } 50 \mathrm{~cm} / \mathrm{h} \\
\text { Rock of middle hardness : } 35 \mathrm{~cm} / \mathrm{h}\end{array}$ \\
\hline
\end{tabular}

3.2 Main body of the deep foundation full face excavator

Photo 1 and Fig. 3 show the appearance and structure of the excavator.

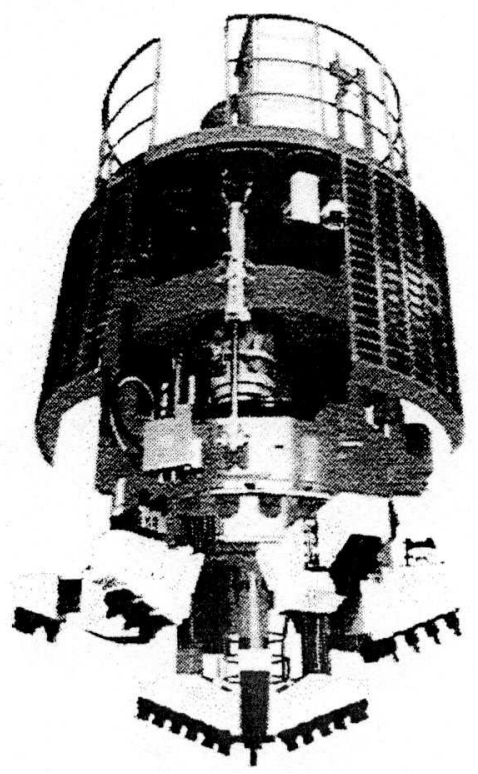

Photo 1 Appearance of the deep foundation full-face excavator

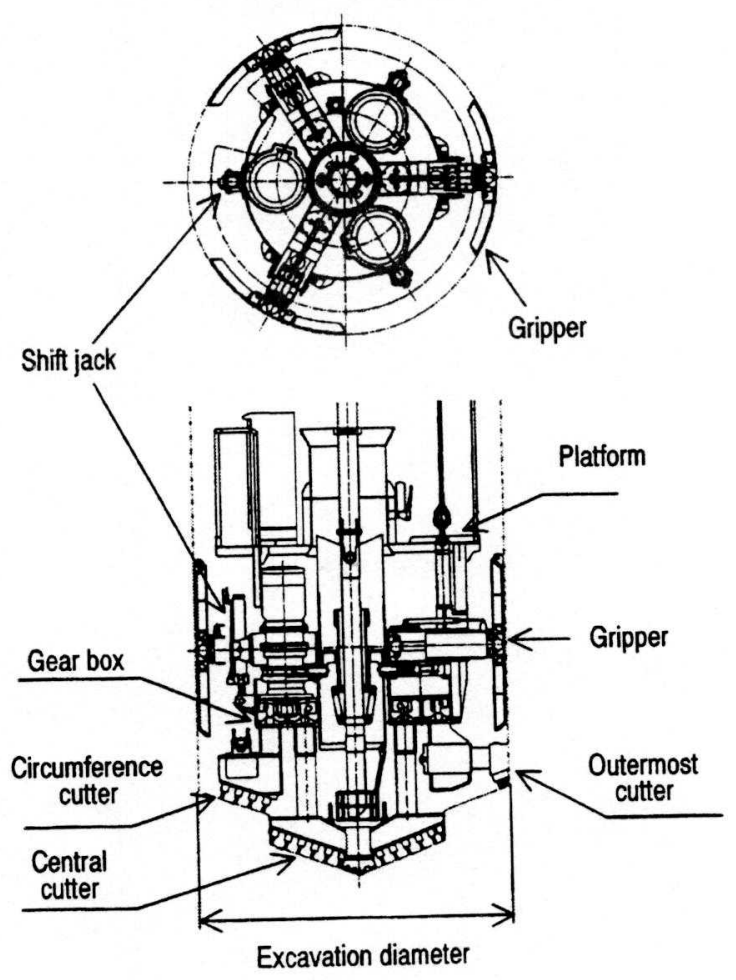

Fig. 3 Structure of the excavator 
Fig. 4 shows the excavation steps, they are

Step1: The excavator presses its three gripper plates to the shaft wall with hydraulic jacks to secure its body against the wall.

Step2: For the full face excavation, the excavator extends its propelling jacks to press the rotating cutter to the cutting face.

Step3: After each stroke of jacking for propelling ( 1 shift : $50 \mathrm{~cm}$ ), the grippers release their holding.

Step4: The propelling jacks retracted to let the excavator body descend.

Next cycle: The grippers are extended again to secure the excavator body by reaction from the wall to perform the excavation of the next shift.

The excavator repeating four steps in order, can advance with a cycle length of $50 \mathrm{~cm}$.

The excavator is given the following features:

(1) All the in-shaft operations from excavation to mucking can be remote-controlled with a single operator on the surface, without human intervention.
(2) The cutter is composed of a center cutter and a circumference cutter which are designed so as to turn inversely to each other for cutting. Use of this mechanism allows us to miniaturize the main frame, with the possibility to compensate torsional moment generating by rotation of the cutters in opposite direction.

(3) The central cutter is arranged with a level difference with the circumference cutter, by which the cutting surface created is slanted so that muck gathers by gravity to the center of the cutter face; therefore, the muck gathered can be carried out easily through a mucking pipe running in the spine of the excavator.

(4) The system is designed with an outermost cutter of telescopic type so that the cutting diameter can be adjusted from $2.65 \mathrm{~m}$ to $3.35 \mathrm{~m}$.

(5) The whole assembly can be divided into elements weighing respectively 2.0 tons or less; even if the site concerned is located in a mountain area, their hauling is easy on cableway or on helicopter.
Step1:

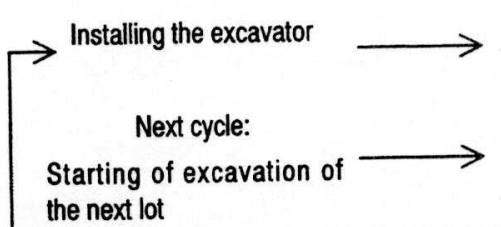

Step2:

Excavation
Step3:

Completion excavation reduction in diameter of grippers
Step4: Retraction of propelling jacks and lowering of excavation unit

\section{Element in action}

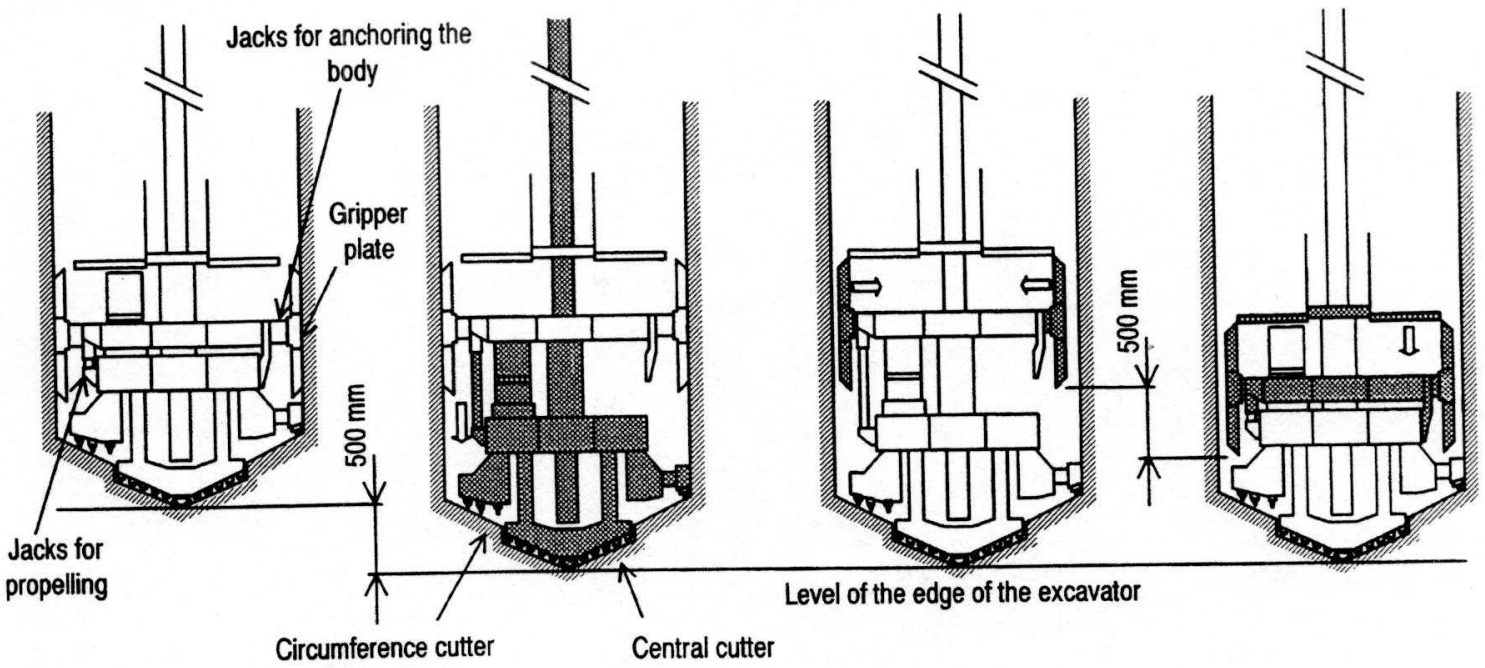

Fig. 4 Propelling steps of the deep foundation full face excavator 


\subsection{Vacuum suction mucking system}

For mucking, the shaft excavator, which is provided with a vacuum suction system of pneumatic type to discharge to the surface the muck collected at the center of the cutting face, is able to perform mucking continuously during excavation. The mucking system consists of a pipe to collect muck, a soil or a dust/air separating dust collector and a vacuum suction unit which generates suction force (rotary blower).

The mucking system is shown in Fig. 5.

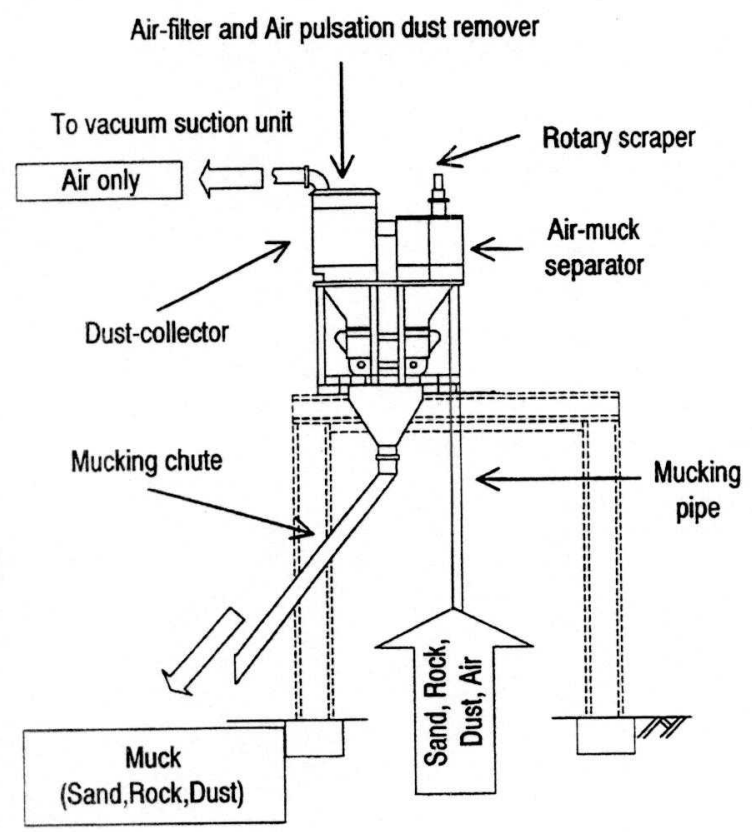

Fig. 5 Mucking system

\subsection{Control system}

Operation of the excavator is performed by a single person from a remote control unit (Photo 2) in the control room on the surface, referring to the data below:

(1)Muck sucking from the mucking pipe inlet, rock mass conditions of the cutting face and of the shaft wall. (monitored by $3 \mathrm{CCD}$ cameras mounted on the excavator)

(2)Hydraulic pressure and shitting speed stroke for shift jacks and gripper jacks.

(3)Inclination of the excavator from horizontal plane. (monitoring by biaxial inclinometer mounted on the excavator)

(4)Cutter load amperage.

(5) Suction force by vacuum suction unit.

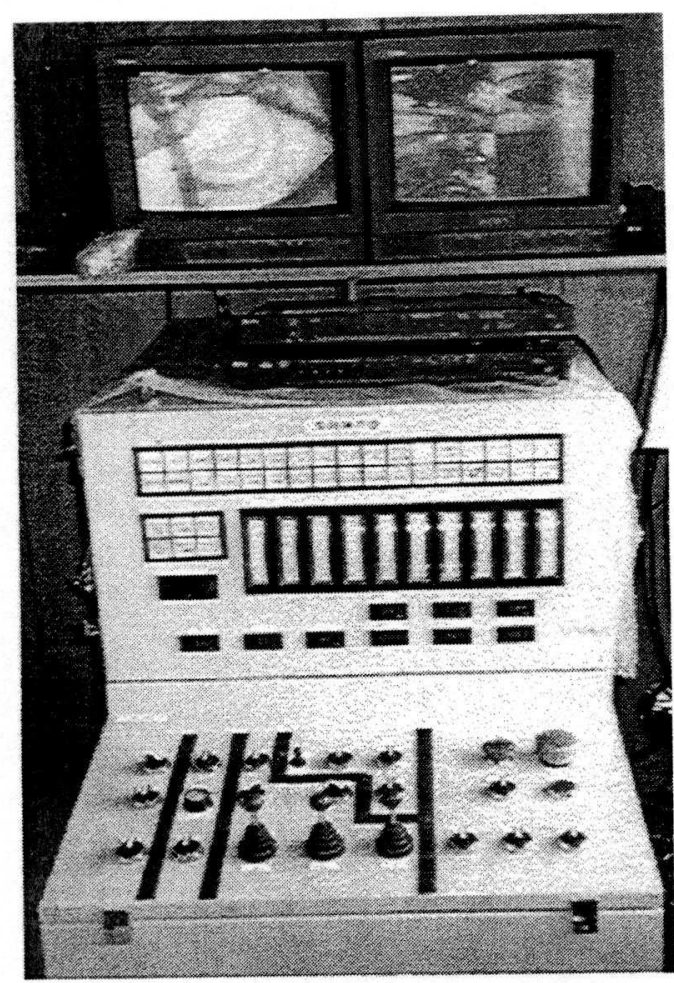

Photo 2 Remote controller

\subsection{Suspension unit}

The suspension unit is composed of a gantry type platform with 4 legs provided above the shaft, and three 5 tons hoists; with this suspension unit, it is possible to carry in and out the excavator, and to place the reinforcement cage into the shaft. The platform is designed with additional leg elements so that it may be installed on an inclined ground surface.

\section{Omission of temporary earth retaining}

Usually, temporary earth retaining is provided to prevent shaft wall from collapsing, with the purposes: (a) security of workers in the shaft, (b) protection of materials and machines and (c) protection of the equipment provided in site.

Since the in-shaft unmanned excavation method is designed especially for the rock mass of a sufficient selfstanding force, as far as the ground concerned is sufficient in these condition, this method can be applied without problem, omitting temporary earth retaining; therefore, we can expect a considerable cost down and shortening of construction period.

The self-standing capability of a shaft wall can be estimated based upon the nature and physical properties of the rock mass in site, as well as on the depth of the excavation level. 
For this work, a chart of shaft-standing sections was prepared using the boring survey data of the site to determine the areas needing no temporary earth retaining; the use of this chart enables to locate the section having self-standing force, on the results of boring survey which are available for many points in the site, and on the FEMdata in terms of the behaviors of the site under excavation.

This procedure needs to implement a preliminary geological review of the site by boring survey on the construction site, so that for the sections of sufficient selfstanding force, we may proceed with excavation resorting to no earth retaining.

\section{Placing of reinforcement cage}

This procedure is to place reinforcement cage in the shaft ; first of all, a cage is assembled just above the shaft, lowered and set in place with a suspension unit. The placement of a cage into the shaft is shown in Photo 3 . This procedure's steps are illustrated in Fig.6.

The assembly of the reinforcement cage are divided into several lots according to their placement depth; they are jointed sequentially on the surface before being lowered into the shaft. The main reinforcement bars of the cage are of screwed type, and coupler-joints used for connecting the lots, enabling continuous construction of plural lots and simplifying the coupler joints-related works.

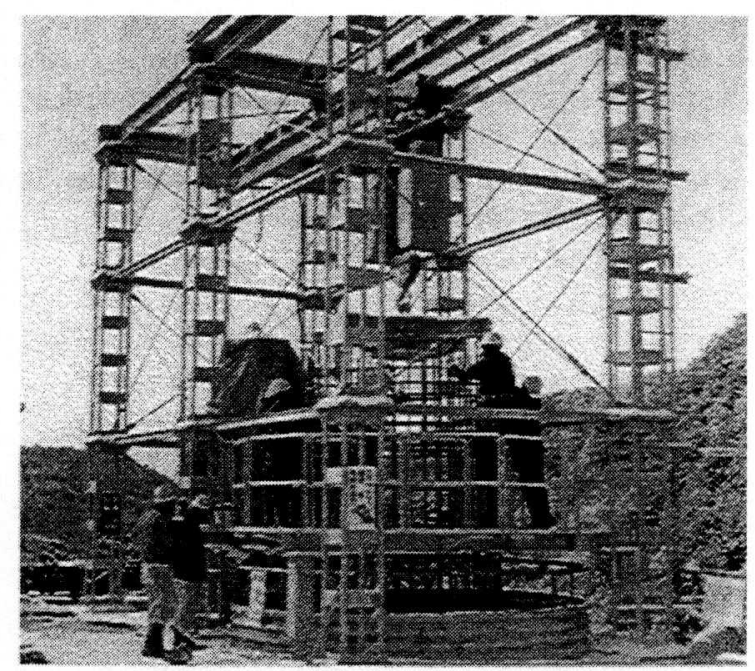

Photo 3 Reinforcement cage-placing method

\section{(1) Assembling}

A reinforcement cage is assembled on platform.
(2) Placing

The cage is suspended, lowered and positioned in place by suspending unit.
(3) Connection of reinforcement lots

The preceding cage is fixed temporally, and the subsequent cage is assembled and connected to the preceding cage.

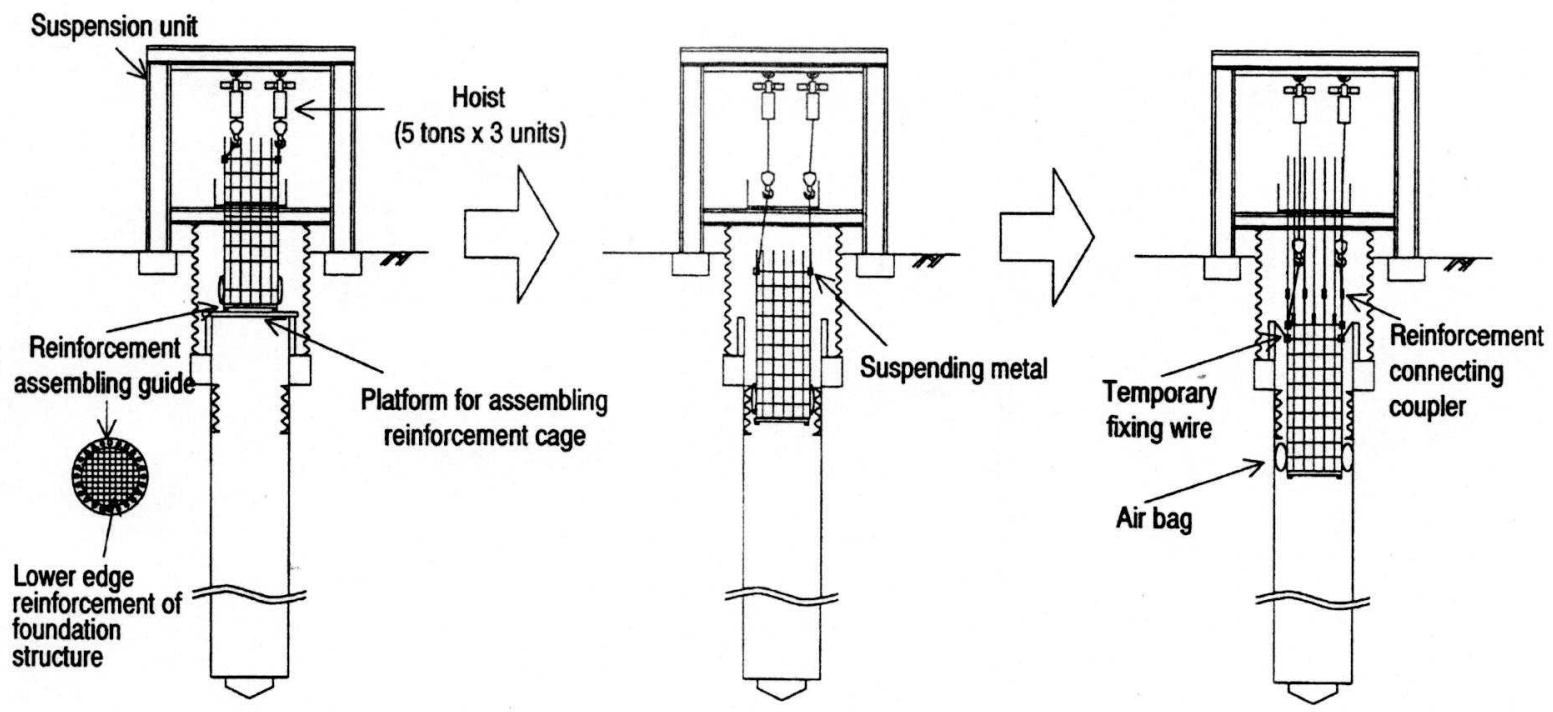

Fig. 6 Steps of placing reinforcement cages in shaft 


\section{Self-settling concrete}

In order that concrete placing in the shaft may be performed unmanned, it is necessary to establish a new concreting procedure needing no filling nor compaction . To meet this requirement, use of one of the high performance concretes recently developed is considered to be effective; however, since this type of concrete is composed of not only cement but also other powder agent, it cannot be prepared by an ordinary butcher plant and is costly.

Paying attention to the fact that the density of bar arrangement is not so high in the case of the deep foundation for steel transmission towers, we have developed a new type concrete, "self-settling concrete for deep foundation", which is smaller in flowability than the concretes of high flowability, but has an excellent resistance in segregation.

This concrete is given the desired flowability and the desired segregation resistance, by use of $\mathrm{AE}$ waterreducing agent and mix-proportion regulation. Use of this material enabled to omit filling and compaction of concrete in the shaft. Tables 3 and 4 show the performances and mix proportion of the concrete required for this project.

Table 3 Required performance of self-settling concrete for deep foundation

\begin{tabular}{|l|l|}
\hline \multicolumn{1}{|c|}{ Item } & \multicolumn{1}{|c|}{ Performance } \\
\hline Nominal strength & $21 \mathrm{~N} / \mathrm{mm}^{2}$ \\
\hline Slump flow & $50 \mathrm{~cm}$ \\
\hline $\begin{array}{l}\text { Time during which concrete keeps } \\
\text { its flowability }\end{array}$ & $90 \mathrm{~min}$. \\
\hline Air content & $4.5 \%$ \\
\hline Bleeding rate & $5 \%$ or less \\
\hline
\end{tabular}

Table 4 Mix proportion of the self-settling concrete for deep foundation

\begin{tabular}{|c|c|c|c|c|c|c|c|}
\hline \multirow{3}{*}{$\begin{array}{c}\text { Water cement } \\
\text { ratio } \\
(\%)\end{array}$} & \multirow{3}{*}{$\begin{array}{c}\text { Aggregate ratio } \\
\text { (\%) }\end{array}$} & \multicolumn{5}{|c|}{ Specific material content $\left(\mathrm{kg} / \mathrm{m}^{3}\right)$} & \multirow{3}{*}{$\begin{array}{c}\text { Admixture rate } \\
(\mathrm{C} \times \%)\end{array}$} \\
\hline & & \multirow[b]{2}{*}{ Cement } & \multirow[b]{2}{*}{ Water } & \multicolumn{2}{|c|}{ Fine aggregate } & \multirow{2}{*}{$\begin{array}{c}\text { Coarse } \\
\text { aggregate }\end{array}$} & \\
\hline & & & & $\begin{array}{l}\text { Coarse } \\
\text { sand }\end{array}$ & Fine sand & & \\
\hline 41.6 & 48.9 & 375 & 156 & 687 & 170 & 896 & 1.90 \\
\hline
\end{tabular}

\section{Demonstration tests}

For the purpose of putting this method into practical use, its applicability to actual use was tested at factory and at field. The test was conducted in two steps; the first step is an element test for each of all the elementary procedures, and the second is a comprehensive test to verify the overall process of the system.

\subsection{Test of the full-face excavator for deep foundation}

(1) Preliminary test At the factory having manufactured this system, test grounds were provided to testify, as preliminary experiment, six cases to simulate excavation performance by the excavator. The excavation diameter was $2.6 \mathrm{~m}$. The excavation propelling speed was $90 \mathrm{~cm} / \mathrm{h}$ in gravel-mixed cohesive soil and $30 \mathrm{~cm} / \mathrm{h}$ in rook mass of middle hardness; the speed achieved was about 3 times larger than conventional excavation methods.

(2) Field-excavation test

To confirm performance, required manpower, processes and safety by excavation system, a demonstration test was conducted at a field through construction of a $500 \mathrm{kV}$ steel transmission tower. The test was conducted for two cases different in ground properties, as shown in Table 5.

(3) Improvement of the excavator

The excavator was improved based upon the test results.

-Use of lime water-absorbing agent

As far as generation of mine water is limited, the viscosity of soil was confirmed to be reduced by using lime water absorbing agent to prevent the mucking pipe from clogging.

- Reviewing the mucking system

The structure of the mucking system was redesigned so as to collect earth and dust separately, resulting in the reduction of the dust which is discharged into the atmosphere. -Reviewing the structure of the mucking pipe inlet

A large screen cage was provided at the suction inlet to prevent large pieces of stone from entering directly into the mucking pipe. 


\subsection{Comprehensive test of the system}

For the unmanned deep foundation construction method in shaft, its field test was conducted to verify all the aspects in applicability of the system at a site of a 500 $\mathrm{kV}$ steel transmission tower. The results of the test were shown in Table 6. Photo 4 shows the appearance of the comprehensive test site. Through this comprehensive test, we have verified: performance of each type of work, consistency between work types and consistency with temporary equipment; their applicability to practical use are confirmed positively.

Table 5 Operation tests of the deep foundation full-face excavator

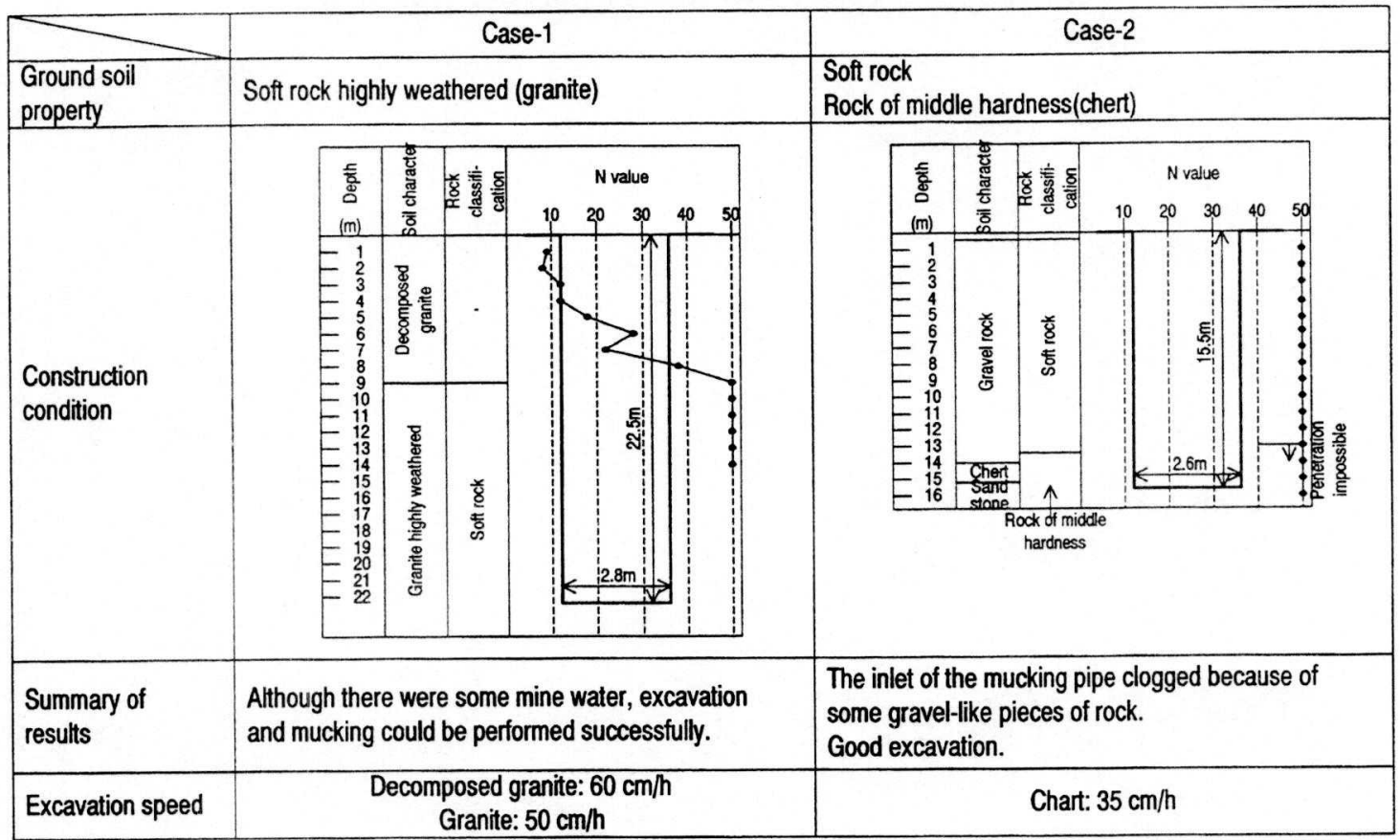

Table 6 Result of comprehensive test for the in-shaft unmanned excavation method

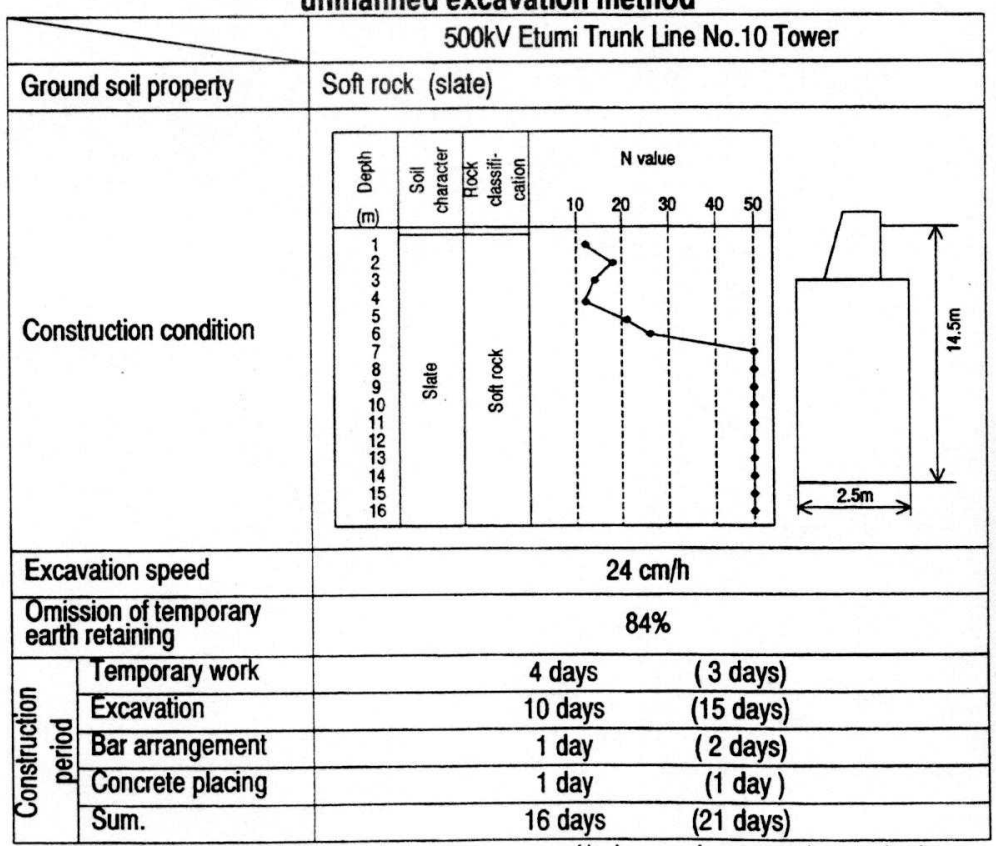

(): by usual construction method

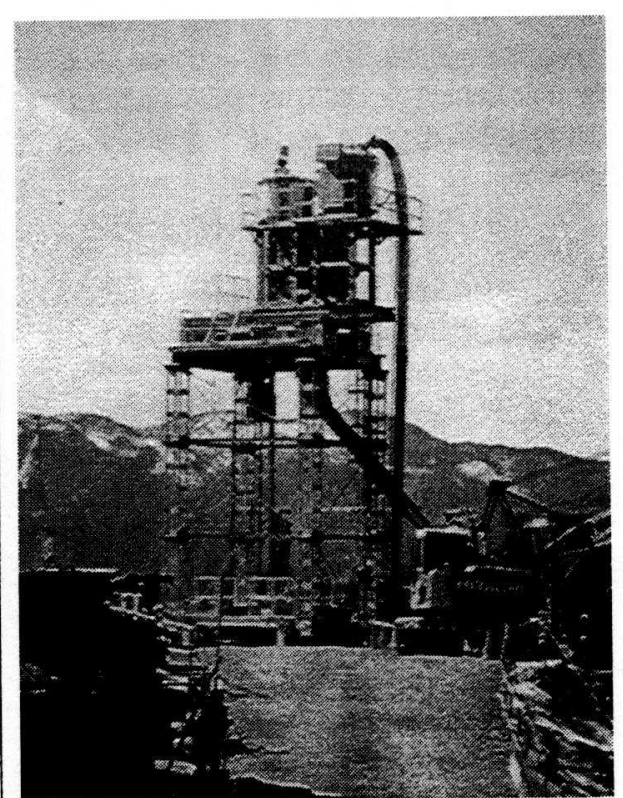

Photo 4 Comprehensive test of the system 


\section{The effects expected by the introduction of the system}

When introducing the in-shaft unmanned deep foundation construction method, the following strengths can be expected

(1) Improvement of working environment: attenuation of working load, shifting from in-shaft work to onsurface work.

(2) Enhancement of safety: unmanning of in-shaft works, needing no explosive.

(3) Labor saving: reduction of manpower for a working group. ( from 8 persons to 5 persons )

(4) Shortening of the working period: from 4 months/tower to 3 months/tower

(5) Reduction of cost: $2 \sim 3 \%$ (when $80 \%$ of the temporary earth retaining can be omitted).

\section{Conclusion}

All the procedures constituting the system from excavation to concrete placing are confirmed for their respective applicability to practical use, through their field tests.

Based upon the demonstration test results, we prepared a manual of execution for the method of the in-shaft unmanned deep foundation construction, covering operation procedures, setting of individual machines and equipment, method of transportation and quality control standards.

This method has been used from April, 1996 at various construction sites of trunk line transmission towers, including those on $500 \mathrm{kV}$ Etsumi trunk line, and with additional improvements and reformations, will be extended in application. 